\title{
Prevalence and Risk Factors Associated with Aeromonas hydrophila infection in Clarias gariepinus and Pond Water from Fish Farms in Kaduna State, Nigeria.
}

\author{
Deborah A. Adah ${ }^{1, *}$, Lawal Saidu ${ }^{2}$, Sonnie J. Oniye ${ }^{3}$,Haruna M. Kazeem ${ }^{4}$, Sylvanus \\ A. Adah $^{5}$ \\ ${ }^{1}$ Department of Veterinary Medicine, University of Ilorin, Ilorin, Nigeria; ${ }^{2}$ Veterinary Teaching Hospital, Ahmadu Bello University Zaria, \\ Nigeria; ${ }^{3}$ Department of Zoology, Ahmadu Bello University, Zaria $;{ }^{4}$ Department of Veterinary Microbiology, Ahmadu Bello University Zaria, \\ Nigeria; ${ }^{5}$ Department of Veterinary Physiology and Biochemistry, University of Ilorin, Ilorin. Nigeria.
}

Received: March 17, 2020; Revised: September 18, 2020; Accepted: September 22, 2020

\begin{abstract}
Clarias gariepinus remains important among fish species, and its farming in Africa has contributed immensely to fast growth in pisciculture. However, the successful rearing of fish is hampered by the occurrence of disease. The study was carried out to establish the prevalence, risk factors associated with, and antibiotic susceptible patterns of Aeromonas hydrophila isolates from C. gariepinus obtained from fish farms in the study area in Kaduna state, Nigeria. Two hundred and fifty-five (255) fish samples with their respective pond water from 30 randomly selected fish farms in Kaduna state were examined for the prevalence of Aeromonas hydrophila. The prevalence of A. hydrophila was 19.6\% (50/255) and 53.3\% $(16 / 30)$ in fish and pond water respectively. A. hydrophila infected fish exhibited erosions and haemorrhages on the skin and fin and degeneration of the fin and barbell. The age, weight, and holding facilities were significantly associated with the prevalence of $A$. hydrophila. Multidrug resistance (MDR) ability ranging from two to seven commonly used antibiotics and twelve resistant patterns was also displayed by the isolates. The presence of $A$. hydrophila with associated MDR characteristics portends public and aquatic health hazards and, therefore, needs active surveillance and monitoring.
\end{abstract}

KeyWords: Aquaculture, Antibiotics, Clarias gariepinus, management practise, multi-drug resistance

\section{Introduction}

Wild fish stock is declining worldwide mainly due to overfishing and climate change, paving the way to the rapid development of fish farming. Fish farming is the world's fastest thriving sector of animal production, involving the use of water (FAO, 2017). Fish takes a prominent place as a source of protein compared to other protein sources and is estimated to provide at least $50 \%$ of total animal protein intake in developing countries (Ugwem et al., 2011; Obiero et al., 2019). However, the successful rearing of Clarias gariepinus (C. gariepinus) is hampered by the occurrence of disease, which at any stage of the fish culture will have a great consequence on the economic viability of fish farms and the yield of protein for human consumption (Babek et al., 2015; Opiyo et al., 2018).

Aeromonas hydrophila (A. hydrophila) is known to be one of the most important bacteria associated with disease in marine, freshwater and cultured fish (Pękala-Safińska, 2018), and infection by A. hydrophila has been recognized for many years and has been associated with brown patch skin disease, tail and fin rot, motile aeromonad septicaemia and haemorrhagic septicaemia which can lead to huge mortality among wild and cultured fishes (Plumb and Hanson, 2011; Bebak et al., 2015).
Aeromonas hydrophila is a ubiquitous Gram-negative bacterium, facultatively anaerobic, oxidase-positive, and glucose-fermenting bacteria belonging to the family Aeromonadaceae (Hussain et al.,2014; Stratev and Odeyemi, 2015), which is commonly isolated from freshwater ponds and inhabits the gastrointestinal tract and are considered to be emerging bacterial pathogens (Igbinosa et al., 2012). More so, A. hydrophila has also been reported to cause zoonotic diseases leading to intestinal and extra-intestinal diseases in humans such as septic arthritis, diarrhoea (traveller's diarrhoea), gastroenteritis, skin and wound infections, meningitis, and fulminating septicaemia (Salunke et al.,2015).

Diseases associated with $A$. hydrophila may have led to an increase in antibiotics application in the fish farms to manage infections and mixtures of antibiotics in feeds resulting in antibiotic resistance among pathogenic bacteria. This is a more challenging problem in developing countries (Wegener and Frimodt-Moller, 2000). Reports on the prevalence of $A$. hydrophila from C. gariepinus and pond water in Kaduna state, Nigeria are scanty. Hence, this study is undertaken to ascertain the prevalence, risk factors associated with, and antibiotic susceptible patterns of $A$. hydrophila isolates from C. gariepinus and pond water from fish farms in the study areas.

\footnotetext{
* Corresponding author e-mail: adah.ad@unilorin.edu.ng.
} 


\section{Materials and method}

\subsection{Study Location}

The study was conducted in Kaduna State, where 4 Local Government Areas (LGAs) including Sabo-Gari, Kaduna-South, Kaduna North, and Zaria LGAs were chosen by random sampling.

Kaduna State is situated in the North -Central region of Nigeria (with Kaduna town as its capital) and shares common borders with Zamfara, Katsina, Niger, Kano, Bauchi, and Plateau States and to the South-West, the Federal Capital Territory, and Abuja. The global location of the State is $10^{\circ} 20^{\prime} \mathrm{N}, 7^{\circ} 45^{\prime} \mathrm{E} 10.333^{\circ} \mathrm{N}$. The State occupies an area of approximately 48,473.2 square kilometres and has a population of more than 6 million people (KSGC, 2017).

\subsection{Sample Collection}

A stratified random sampling method was employed, in which four Local Government Areas (LGAs) and thirty fish farms were selected comprising 40 concrete ponds, 26 earthen ponds, and 22 plastic tanks making a total of 88 holding facilities within which fish and water were selected. A range of 5-15 fish/ponds were selected based on the stocking density and water samples were collected from 2-6 holding facilities based on the number of holding facilities on the farms (Table 1). A total of two hundred and fifty-five fish samples were conveyed in a plastic receptacle with a cover having the pond water. Also 88 water samples each measuring $500 \mathrm{ml}$ were collected from ponds using sterile bottles and transported under the cold chain to the Veterinary Microbiology laboratory of Ahmadu Bello University Zaria for analyses.

Table 1. Distribution of selected fish holding facilities in 4 LGAs in Kaduna State.

\begin{tabular}{lllll}
\hline LGA & $\begin{array}{l}\text { NO OF } \\
\text { FARMS }\end{array}$ & $\begin{array}{l}\text { EARTHEN } \\
\text { POND }\end{array}$ & $\begin{array}{l}\text { CONCRETE } \\
\text { POND }\end{array}$ & $\begin{array}{l}\text { PLASTIC } \\
\text { TANK }\end{array}$ \\
\hline Sabo Gari & 5 & 0 & 16 & 3 \\
$\begin{array}{l}\text { Kaduna } \\
\text { North }\end{array}$ & 11 & 14 & 0 & 10 \\
$\begin{array}{l}\text { Kaduna } \\
\text { South }\end{array}$ & 8 & 5 & 12 & 6 \\
Zaria & 6 & 7 & 12 & 3 \\
\hline TOTAL & 30 & 26 & 40 & 22 \\
\hline
\end{tabular}

Clarias gariepinus samples were examined clinically, by taking history and conducting antemortem, and postmortem procedures after which each fish was tagged (Kwaga et al., 1988; (Kwaga et al., 1988; Austin and Austin, 2012). The age, sex, and gross lesions were observed and recorded. Each live fish was sacrificed (by brain spiking to minimise suffering) and placed on a clean stainless tray dorsally, and swab (sterile cotton wool soaked in $70 \%$ alcohol) was used to clean the fish from the operculum to the abdominal area to reduce bacterial load.

\subsection{Bacterial culture and isolation of Aeromonas hydrophila}

The isolation of Aeromonas hydrophila followed the standard procedure described by Cowan and Steel (1974). For each fish, the gastrointestinal tract was excised and macerated, and $10 \%$ of it was inoculated into a test tube containing enrichment broth (Alkaline peptone water) $\mathrm{pH}$,
8.6. The glass tubes were incubated at $37^{0} \mathrm{C}$ for $18-24$ hours. This was then subcultured onto MacConkey agar. Also, water samples collected from each farm were pooled and centrifuged at 3,000 rpm for 10 minutes. The sediment was inoculated into alkaline peptone water and incubated at $37^{\circ} \mathrm{C}$ for $18-24$ hours and later subcultured onto MacConkey agar (Buchanan and Gibbons, 1974).

Biochemical tests were carried out for on the isolated Gram-negative bacteria (non-lactose fermenters) included catalase test, citrate utilization test, haemolysis of sheep Red Blood cells, hydrogen sulphide production, indole test, methyl red test, oxidase test, sugar fermentation tests (glucose, sorbitol, sucrose, lactose, rhamnose, and galactose), urease test, and Voges -Proskauer test.

All the chemicals used for biochemical tests were set according to manufacturer instructions (Difco ${ }$, Laboratories, USA and Oxoid ${ }^{\circledR}$, London, UK) and the results were interpreted using the manual for bacteria identification (Cowan and Steel, 1974) and online ABIS Advanced Bacteriological Identification Software (ABIS, 2017).

\subsection{Antibiotic sensitivity of the bacterial isolates}

The antimicrobial susceptibility of 50 and 16 Aeromonas hydrophila isolates from fish and pond water, respectively, were ascertained using the disc diffusion method. The antibiotics were selected based on their common use in the fish farms and these included Ampicillin $(10 \mu \mathrm{g})$, Chloramphenicol $(10 \mu \mathrm{g})$ Gentamycin (10 $\mu \mathrm{g})$, Oxacillin $(5 \mu \mathrm{g})$, Penicillin (10 units), Streptomycin $(10 \mu \mathrm{g})$, Tetracycline $(30 \mu \mathrm{g})$, and Vancomycin $(5 \mu \mathrm{g})$. The susceptibility test was carried out on Muller Hinton agar using antibiotic-impregnated discs. Zones of inhibition were compared with reference strain (ATCC 646) and interpreted as sensitive, intermediate, and resistant (CLSI, 2011).

\subsection{Statistical Analysis}

Data from this study were loaded into Microsoft Office Excel version 2016 for establishing the frequencies and percentages (\%). Chi-square test was used to assess the discrete variables at a 95\% confidence interval at $\mathrm{p}<0.05$ was considered to ascertain the associations of potential risk factors with the isolate on of $A$. hydrophila in the study area. The Statistical Package for the Social Sciences (SPSS, Chicago, Illinois, USA) for windows version 22.0 was used for all analysis, and p-value $<0.05$ was considered significant in all the analyses.

\section{Results}

\subsection{Clinical manifestations and prevalence rate of Aeromonas hydrophila in C. gariepinus}

The Clarias gariepinus samples comprised of 200 clinically sick and 55 apparently healthy ones aged between $4-24$ weeks and measuring 15-42 cm in length, $3.8-12 \mathrm{~cm}$ in width, and 200-1000g in weight. Among the sick Clarias gariepinus, observations such as anorexia and sluggish movements were observed. On physical examination, one or more of the following were observed, which include: exophthalmia (protrusion of the eyeball), erosions, and severe haemorrhages on the skin, eyes, barbels, and fin. Fin rot, white spot, oedema petechiation, and hyperemia of the abdomen. Post-mortem examination 
of the sick fish revealed pale gills, congestion of liver, kidney, and spleen, distended gallbladder, and yellowishgreen mucoid in the intestine.

The highest isolation rate of $A$. hydrophila was $33.3 \%$ (9/27) obtained from sick fish in Sabo Gari LGA, while the least isolation rate of $13.4 \%$ (9/67) was obtained from Kaduna South LGA. More so, among the apparently healthy fish, the isolation rate was up to $23.1 \%(3 / 13)$ in Kaduna South LGA. However, there was no significant difference $(P>0.05)$ within the different locations sampled. The prevalence of $A$. hydrophila was $28.1 \%$, $20.7 \%$, $20 \%$, and $15 \%$ obtained from C. gariepinus gotten from Sabo Gari (9/32), Zaria (12/58), Kaduna North (17/85), and Kaduna South (12/80) respectively (Table 2). A total of 50 A. hydrophila, 43 (21.5\%) from sick (n= $200)$ and $7(12.7 \%)$ from apparently healthy $(n=50)$ were obtained from Clarias gariepinus respectively given a total prevalence rate of $19.6 \%(50 / 255)$, but there was no significant difference $(P>0.05)$ between the fish sampled (Table 2).

The prevalence of $A$. hydrophila infection increases with the age, weight, and length of $C$. gariepinus. The likelihood of infection with $A$. hydrophila in female $C$. gariepinus was 1.41 times when compared to their male counterpart. $C$ gariepinus managed semi-intensively were 1.46 times more likely to be infected with $A$. hydrophila when compared to $C$. gariepinus raised in the intensive system, while sick $C$. gariepinus were 1.87 times likely to be infected with $A$. hydrophila when compared with the healthy ones. There was a higher infection tendency of 2.98 of $A$. hydrophila among $C$. gariepinus raised in earthen ponds and 2.70 times likely to occur in fish raised in a concrete tank. There was no significant difference in the prevalence of $A$. hydrophila from the different sampled Local Government Areas.

However, the prevalence was higher in $C$. gariepinus sampled in Sabo Gari LGA. The association between age, (1-3, 4-6, and 7-9months), weight (201-400g and 401-600g), and holding facilities (concrete and earthen ponds) with the prevalence of $A$. hydrophila was statistically significant at $\mathrm{p}<0.05$. The prevalence rate of $24 \%, 22.2 \%$, and $9.5 \%$ was obtained from $C$. gariepinus in earthen ponds, concrete ponds, and plastic tanks, respectively, although there was no significant difference $p>0.05$ (Table 3).

Table 2. Prevalence of Aeromonas hydrophila in sick, apparently healthy fish and pond water obtained from four LGAs in Kaduna State.

\begin{tabular}{|c|c|c|c|c|c|c|c|c|}
\hline LGA & NFS & $\begin{array}{l}\text { No. of } A \text {. hydrophila } \\
\text { isolate (\%) }\end{array}$ & $\begin{array}{l}\text { P-Value } \\
\text { (NFS) }\end{array}$ & NFS & $\begin{array}{l}\text { No. of } A \text {. hydrophila } \\
\text { isolate }(\%)\end{array}$ & NPWS & $\begin{array}{l}\text { No. of } A \text {. hydrophila } \\
\text { isolate }(\%)\end{array}$ & $\begin{array}{l}P \text {-Value } \\
\text { (NPWS) }\end{array}$ \\
\hline Sabo Gari & & & & 32 & $9(28.1)$ & 5 & $2(40.0)$ & \multirow{15}{*}{0.56} \\
\hline $\begin{array}{l}\text { Apparently } \\
\text { healthy }\end{array}$ & 5 & $0(0.0)$ & 0.16 & & & & & \\
\hline Sick & 27 & $9(33.3)$ & & & & & & \\
\hline Kaduna North & & & & 85 & $17(20.0)$ & 11 & $7(63.7)$ & \\
\hline $\begin{array}{l}\text { Apparently } \\
\text { healthy }\end{array}$ & 22 & $3(13.6)$ & 0.39 & & & & & \\
\hline Sick & 63 & $14(22.2)$ & & & & & & \\
\hline Kaduna south & & & & 80 & $12(15.0)$ & 8 & $5(62.5)$ & \\
\hline $\begin{array}{l}\text { Apparently } \\
\text { healthy }\end{array}$ & 13 & $3(23.1)$ & 0.37 & & & & & \\
\hline Sick & 67 & $9(13.4)$ & & & & & & \\
\hline Zaria & & & & 58 & 12 (20.7) & 6 & $2(33.3)$ & \\
\hline $\begin{array}{l}\text { Apparently } \\
\text { healthy }\end{array}$ & 15 & $1(6.7)$ & 0.12 & & & & & \\
\hline Sick & 43 & $11(25.6)$ & & & & & & \\
\hline Total NFS & & & & & & & & \\
\hline $\begin{array}{l}\text { Apparently } \\
\text { healthy }\end{array}$ & 55 & $7(12.7)$ & 0.14 & & & & & \\
\hline Sick & 200 & $43(21.5)$ & & & & & & \\
\hline Total & 255 & 50 (19.6) & & 255 & 50 (19.6) & 30 & 16 (53.3) & \\
\hline
\end{tabular}

Key: NFS: Number of fish sampled; NPWS: Number of pooled pond water sample 
Table 3. Prevalence and risk factors associated with A. hydrophila infection in C. gariepinus from 4 LGAs in Kaduna State.

\begin{tabular}{|c|c|c|c|c|}
\hline Risk Factors & $\mathbf{N}$ & Prevalence (\%) & OR $(95 \%$ CI $)$ & $P$-Value \\
\hline \multicolumn{5}{|l|}{ Sex } \\
\hline Female & 105 & $24(22.86)$ & $1.41(0.75-2.64)$ & 0.28 \\
\hline Male $^{\mathrm{a}}$ & 150 & $26(17.33)$ & 1.00 & \\
\hline \multicolumn{5}{|l|}{ Weight(g) } \\
\hline $0-200$ & 44 & 8 (18.18) & & \\
\hline $201-400$ & 96 & $10(10.42)$ & $0.08(0.02-0.34)$ & $<0.01^{*}$ \\
\hline $401-600$ & 53 & $12(22.64)$ & $0.20(0.04-0.85)$ & $0.03 *$ \\
\hline $601-800$ & 35 & $9(25.71)$ & $0.24(0.05-1.07)$ & 0.06 \\
\hline $801-1000$ & 12 & $5(41.67)$ & $0.49(0.08-2.81)$ & 0.43 \\
\hline$>1000^{\mathrm{a}}$ & 10 & $6(60.00)$ & 1.00 & \\
\hline \multicolumn{5}{|l|}{ Total Length (cm) } \\
\hline$<20$ & 20 & $2(10.00)$ & $0.31(0.04-1.38)$ & 0.14 \\
\hline $21-30$ & 45 & $7(15.56)$ & $0.52(0.18-1.41)$ & 0.20 \\
\hline $31-40$ & 72 & $14(19.44)$ & $0.67(0.29-1.59)$ & 0.66 \\
\hline $41-50$ & 65 & $13(20.00)$ & $0.70(0.29-1.67)$ & 0.42 \\
\hline $51-60^{\text {a }}$ & 53 & $14(26.42)$ & 1.00 & \\
\hline \multicolumn{5}{|l|}{ Age (months) } \\
\hline $1-3$ & 70 & $8(11.43)$ & $0.07(0.02-0.23)$ & $0.0001^{*}$ \\
\hline $4-6$ & 85 & $9(10.59)$ & $0.07(0.02-0.21)$ & $0.0001^{*}$ \\
\hline $7-9$ & 56 & $10(17.86)$ & $0.12(0.04-0.38)$ & $0.0001^{*}$ \\
\hline $10-12$ & 23 & $10(43.48)$ & $2.36(0.68-8.59)$ & 0.18 \\
\hline$>12^{\mathrm{a}}$ & 20 & $13(65.00)$ & 1.00 & \\
\hline \multicolumn{5}{|l|}{ Management system } \\
\hline Semi- intensive & 75 & $18(24.00)$ & $1.46(0.75-2.80)$ & 0.2624 \\
\hline Intensive $^{a}$ & 180 & 32 (17.78) & 1.00 & \\
\hline \multicolumn{5}{|l|}{ Health Status } \\
\hline Sick & 200 & $43(21.50)$ & $1.87(0.82-4.77)$ & 0.14 \\
\hline Apparently healthy ${ }^{a}$ & 55 & 7 (9.09) & 1.00 & \\
\hline \multicolumn{5}{|c|}{ Local Government Areas } \\
\hline Sabo Gari & 32 & $9(28.13)$ & $1.49(0.53-4.11)$ & 0.44 \\
\hline Kaduna North & 85 & $17(20.00)$ & $0.96(0.42-2.25)$ & 0.92 \\
\hline Kaduna South & 80 & $12(15.00)$ & $0.68(0.28-1.67)$ & 0.40 \\
\hline Zaria $^{\text {a }}$ & 58 & 12 (20.69) & 1.00 & \\
\hline \multicolumn{5}{|l|}{ Holding facilities } \\
\hline Concrete ponds & 117 & $26(22.22)$ & $2.70(1.08-7.60)$ & $0.03^{*}$ \\
\hline Earthen ponds & 75 & $18(24.00)$ & $2.98(1.13-8.73)$ & $0.03 *$ \\
\hline Plastic tanks ${ }^{a}$ & 63 & $6(9.52)$ & 1.00 & \\
\hline
\end{tabular}

${ }^{\mathrm{a}}=$ Reference category; OR = Odds Ratio; CI = Confidence Interval; * = Significant $P<0.05$

\subsection{Prevalence of A. hydrophila in Pond Water} collected from the sampled location

Aeromonas hydrophila isolation rates of $63.7 \%, 62.5$ $\%, 40.0 \%$, and $33.3 \%$ were obtained from pond water gotten from Kaduna North (7/11), Kaduna South (5/8\%), Sabo Gari (2/5), and Zaria LGAs (2/6), respectively. The total isolation rate was 53.3\% (16/30) from the pooled pond water (Table 2). The isolation rate of $60 \%(6 / 10)$ was obtained from pooled pond water collected from concrete and earthen ponds while $40 \%(4 / 10)$ was obtained from pooled pond water collected from plastic tanks (Table 2).
The prevalence of $A$. hydrophila was higher in pond water sampled from Kaduna North LGA when compared to Sabo Gari, Kaduna South, and Zaria LGAs. The prevalence was higher and was 2.16 likely to occur in pond water sampled from the earthen and concrete pond when compared to pond water samples from plastic tanks. Consequently, ponds semi intensively managed was 1.48 likely for $A$. hydrophila to occur when compared with ponds intensively managed. There was no significant difference ( $p>0.05)$ in the prevalence of $A$. hydrophila from water samples (Table 4). 
Table 4. Prevalence and risk factors associated with A. hydrophila infection in pond water from 4 LGAs in Kaduna State.

\begin{tabular}{|c|c|c|c|c|}
\hline Risk & $\mathbf{N}$ & Prevalence (\%) & OR $(95 \%$ CI $)$ & P-Value \\
\hline \multicolumn{5}{|c|}{ Local Government Areas } \\
\hline Sabo Gari & 5 & $2(40.00)$ & $1.30(0.09-19.43)$ & 0.85 \\
\hline Kaduna North & 11 & $7(63.63)$ & $3.24(0.39-35.49)$ & 0.29 \\
\hline Kaduna South & 8 & $5(62.50)$ & $3.04(0.32-37.36)$ & 0.35 \\
\hline Zaria $^{\text {a }}$ & 6 & $2(33.33)$ & 1.00 & \\
\hline \multicolumn{5}{|l|}{ Holding facilities } \\
\hline Concrete ponds & 10 & $6(60.00)$ & $2.16(0.35-14.71)$ & 0.42 \\
\hline Earthen ponds & 10 & $6(60.00)$ & $2.16(0.35-14.71)$ & 0.42 \\
\hline Plastic tanks ${ }^{a}$ & 10 & $4(40.00)$ & 1.00 & \\
\hline \multicolumn{5}{|c|}{ Management system } \\
\hline Semi- intensive & 10 & $6(60.00)$ & $1.48(0.31-7.70)$ & 0.63 \\
\hline Intensive $^{\mathrm{a}}$ & 20 & $10(50.00)$ & 1.00 & \\
\hline
\end{tabular}

OR=Odds Ratio, CI=Confidence Interval, a Reference category;

\subsection{Antibiotic susceptibility of the Aeromonas} hydrophila isolates.

The susceptibility test of Aeromonas hydrophila indicated that gentamicin had the highest sensitivity $(66.7 \%$, 44/66) followed by chloramphenicol (48.5 \%, 32/66), streptomycin (15.2 \%, 10/66), oxytetracycline and tetracycline $(6.1 \% 4 / 66)$, respectively, and none to vancomycin, penicillin, and ampicillin. All the $A$. hydrophila isolates were found to be resistant to penicillin (100 \%, 66/66), oxytetracycline (93.9 \%, 62/66), vancomycin $(92.4 \%, 61 / 66)$ ampicillin $(69.7 \%, 46 / 66)$ tetracycline $(60.6 \%, 40 / 66)$, chloramphenicol (36.4 \%,
24/66), streptomycin $(30.3 \%, 20 / 66)$ and gentamicin (9.1 $\%, 6 / 66)$ respectively. There was a statistical significance $p$ $<0.01$ between the sensitive, resistant, and intermediate $A$. hydrophila (Table 5). Multidrug resistance (MDR) was displayed by A. hydrophila isolates to the antibiotics mostly used in pisciculture in Kaduna state, Nigeria. Multidrug resistance of $A$. hydrophila isolates ranged between $2-7$ different antibiotics used, twelve different MDR patterns were observed and the prevalence of MDR among the A. hydrophila ranged between $3.0 \%-15.2 \%$ (Table 6).

Table 5. Antibiotics susceptibility of Aeromonas hydrophila isolated from fish and pond water

\begin{tabular}{|c|c|c|c|c|c|c|}
\hline Antibiotic & Sensitive (\%) & $P$-Value & Intermediate (\%) & $P$-Value & Resistant (\%) & $P$-Value \\
\hline Ampicillin & $0(0.0)$ & \multirow{9}{*}{$<0.01 *$} & $20(30.3)$ & \multirow{9}{*}{$<0.01 *$} & 46 (69.7) & \multirow{9}{*}{$<0.01 *$} \\
\hline Chloramphenicol & 32 (48.5) & & $10(15.2)$ & & $24(36.4)$ & \\
\hline Gentamycin & 44 (66.7) & & $16(24.2)$ & & $6(9.1)$ & \\
\hline Oxytetracycline & $4(6.1)$ & & $0(0.0)$ & & 62 (93.9) & \\
\hline Penicillin & $0(0.0)$ & & $0(0.0)$ & & $66(100.0)$ & \\
\hline Streptomycin & $10(15.2)$ & & $36(54.5)$ & & $20(30.3)$ & \\
\hline Tetracycline & $4(6.1)$ & & 22 (33.3) & & 40 (60.6) & \\
\hline Vancomycin & $0(0.0)$ & & $5(7.6)$ & & $61(92.4)$ & \\
\hline Total & 94 (17.8) & & $108(20.5)$ & & $326(61.7)$ & \\
\hline
\end{tabular}

* = Significant $P<0.05$

Table 6. Multidrug resistance patterns of Aeromonas hydrophila isolated from fish and pond water

\begin{tabular}{llll}
\hline Resistance patterns & $\begin{array}{l}\text { Number of Aeromonas hydrophila } \\
\text { isolates }\end{array}$ & Prevalence (\%) & $P$-Value \\
\hline PEN, OXA, & 5 & 7.6 \\
PEN, OXA, VAN, TET & 10 & 15.2 \\
PEN, OXA, VAN, AMP, & 4 & 6.1 \\
PEN, OXA, VAN, STR, AMP & 5 & 7.6 \\
PEN, OXA, VAN, GEN, STR & 2 & 3.0 \\
PEN, OXA, VAN, TET, CHL & 3 & 4.5 \\
PEN, OXA, VAN, TET, AMP & 10 & 15.2 \\
PEN, VAN, GEN, AMP, CHL & 4 & 6.1 & \\
PEN, OXA, VAN, TET, AMP & 6 & 9.1 & \\
PEN, OXA, VAN, TET, AMP, CHL & 4 & 6.1 & \\
PEN, OXA, VAN, STR, AMP, CHL & 6 & 9.1 & \\
PEN, OXA, VAN, TET, STR, AMP, CHL & 7 & 10.6 \\
\hline
\end{tabular}

PEN: Penicillin; AMP: Ampicillin; CHL: Chloramphenicol; GEN Gentamycin; OXA: Oxacillin STR: Streptomycin; TET: Tetracycline; VAN: Vancomycin 


\section{Discussion}

In this present study, the prevalence rate in $C$. gariepinus was higher than that of Mailafia (2003), who reported a prevalence of $11.6 \%$ in fish from wild sources. These differences could be due to different geographical locations, seasons of the year, species of fish, isolation methods, quality of water, and management practices. Isolation and identification of $A$. hydrophila in apparently healthy $C$. gariepinus were similar to the report of Omeje and Chukwu (2014), where A. hydrophila was isolated in both healthy and diseased fish. Consequently, the isolation in apparently healthy Clarias gariepinus may lead to the outbreak of disease when the water quality and management practices of fish farms become unfavorable for production. The variation of the prevalence rates in the different locations may have been contributed by the differences in the interaction of the pathogen, host, and the environment (Raman et al., 2013). Isolation of $A$. hydrophila in ponds water and $C$. gariepinus in this study showed that it is a natural inhabitant of the culture system in the selected fish farms (Shiranee et al., 1993). The isolation of Aeromonas species in pond water has been described to be an indication of the presence of fish disease on a farm (Noga, 2000). The higher prevalence of $A$. hydrophila in the earthen ponds could be because most of the farms sourced their water from the natural water bodies' that are already contaminated with animal and human activities especially the dumping of refuse which invariably get into the ponds. This development is suitable for the propagation and multiplication of several microorganisms including $A$. hydrophila. More so, $A$. hydrophila is saprophytic and thus their prevalence of $A$. hydrophila is ensuing upon environmental fluctuations and changes (Okpokwasili and Ogbulie, 1999).

It has been documented that A. hydrophila causes disease in both cultured and wild fish and can cause clinical signs to the host tissue. Which may be in the form of haeamorrhages and inflammation (Goharriz et al., 2015; Stratev et al., 2015). Our findings were similar to the clinical manifestation of $A$. hydrophila found in Clarias gariepinus and other fish species (Omeje and Chukwu, 2014; Kumar et al., 2016). Anyanwu et al (2014) and ElBouhy et al. (2015) reported earlier that motile Aeromonads are associated with erosive and heamorrhagic ulcerative skin lesions observed in the present study. Damage to the fish skin has been recognized as a portal of entry for many bacterial pathogens (Long et al., 2014). The different patterns of clinical and pathological manifestations expressed in diseased fish caused by $A$. hydrophila as observed in this study may be due to the difference in individual C. gariepinus susceptibility to $A$. hydrophila (Baumgartner et al., 2017; Mohamed, 2018). The prevalence of $A$. hydrophila in C. gariepinus in our study was less compared to the $30.5 \%$ prevalence rate reported by Omeje and Chukwu (2014), and $31.7 \%$ by Omeje and Chukwu (2012).

There was no bias in the infection of $A$. hydrophila among the $C$. gariepinus based on sex, weight, and length. It has been documented that Aeromonas species affects fishes of all ages and sizes (Camus et al., 1998), but in our study, the isolation rate was in older fish when compared with younger fish. This is contrary to the reports by Mzula et al., 2019 who opined that the infection of $A$. hydrophila was higher in fingerlings than in older fish, our observation could be attributed to the fact that older fish have stayed longer in the different holding facilities increased the exposure to the A. hydrophila. More so, they are bigger in size and this provides a larger surface area for the infection to multiply in number than smaller ones.

Management practise of the fish farms seems to contribute significantly to the isolation of $A$. hydrophila from $C$. gariepinus. In line with this, it was observed that $C$ gariepinus raised in earthen ponds, which are semi intensively managed were more prone to the infection than those raised in concrete and plastic tanks intensively managed. Our findings could be attributed to the high presence of elevated pollution levels and anthropogenic activities in earthen ponds which often causes the $A$. infections in $C$. gariepinus, and so the vulnerability of $C$. gariepinus to pathogenic infections is enhanced (Dar et al., 2016).

A. hydrophila isolates in this study showed a high level of multidrug resistance and were resistant to oxytetracycline, vancomycin, ampicillin, and tetracycline in which Gentamicin had the highest sensitivity. The result obtained in this present study is similar to that reported by Nahar et al. (2016) and Odeyemi and Ahmad (2017). Antibiotic application on fish farms is often practiced as a means of managing diseases on fish farms (Chitmanat et al., 2016), and this practice leads to the increased development of resistance of $A$. hydrophila infection against the antibiotics used (Nahar et al., 2016). This resistance of $A$. hydrophila to routinely used antimicrobial agents is a budding problem in pisciculture (Dias et al., 2012), and the spread of antibiotics resistance is of great concern because $A$. hydrophila is also a zoonotic pathogen (Janda and Abbott, 2010). The excessive and indiscriminate use of penicillin, amoxicillin, oxytetracycline, and vancomycin may have predisposed this current finding. Nahar et al. (2016), reported that Aeromonas hydrophila showed marked levels of resistance against chloramphenicol, penicillin, amoxicillin, metronidazole, sulphamethoxazoletrimethoprim, and amikacin.

The diversity of antibiotic resistance pattern exhibited by $A$. hydrophila encountered in this present study reflects the diversity among the isolates and the challenge of multidrug resistance (MDR) seems to affect many pets, livestock, and aquatic animals and its consequence might be detrimental (Lee and Wendy, 2011; Igbinosa et al., 2012; Daodu et al., 2017). MDR might also reflect the consequence of the irrational use of antibiotics used in fish farms.

\section{Conclusion}

Aeromonas hydrophila is present in pond water and $C$. gariepinus from selected fish farms in Kaduna state harboring multidrug-resistant Aeromonas hydrophila which constitute a potential public health risk and may affect aquatic health. The unregulated antibiotic usage in the aquatic industry in Nigeria has to be keenly scrutinized and monitored from time to time to determine the spread and increase of bacterial resistance. The detection of $A$. hydrophila in fish suggests that strict hygiene procedures 
and proper cooking before consumption of fish is essential to safeguard consumers.

\section{Acknowledgment}

The authors want to appreciate the assistance of all fishermen and laboratory technologists who contributed to the realization of this work.

\section{Statement of Animal Right}

All regulations and international standard involved in the use of animal were duly followed.

\section{Conflict of interest}

The Authors hereby declare that there was no conflict of interest.

\section{References}

ABIS(Advanced Bacteriological Identification Software). 2018. (http://www.tgw1916.net/bacteria_logare_desktop.html). Accessed 12, March 2019.

Anyanwu MU, Chah KF and Shoyinka VS. 2014. Antibiogram of aerobic bacteria isolated from skin lesions of African catfish cultured in South East Nigeria. Int. J. Fish. Aquat. Stud ., 2:134141.

Austin B and Austin DA. 2012. Bacterial fish pathogens: Disease of farmed and wild fish 3rd edition. pp: 112-115.

Baumgartner WA, Ford L and Hanson L. 2017. Lesions caused by virulent Aeromonas hydrophila in farmed catfish (Ictalurus punctatus and $I$. punctatus $\times I$. furcatus) in Mississippi. $J$. Vet. Diagnostic Investig., 29(5): 747-751.

Bebak J, Wagner B, Burnes B and Hanson T. 2015. Farm size, seining practices, and salt use: risk factors for Aeromonas hydrophila outbreaks in farm-raised catfish, Alabama, USA, Prev. Vet. Med.., 118: (1)161-168.

Buchanan RE and Gibbons NE. 1974. Manual of determinative bacteriology, In: ed Bergey's 8th Edition.Williams and Wilkins, Baltimore. pp. 1268.

Camus AC, Durborow RM, Hemstreet WG, Thune RL and Hawke JP. 1998. Aeromonas bacterial infections - motile Aeromonad septicemia. South. Reg. Aquacult. Cent., 478 (1) 1-4.

Chitmanat C, Lebel C, Whangchai C and Lebel L. 2016. Tilapia diseases and management in river-based cage aquaculture in northern Thailand J. Appl. Aquac., 28 (1): 9-16.

Clinical and Laboratory Standards Institute (CLSI), 2011. Performance standards for antimicrobial susceptibility testing; twenty-second informational supplements. CLSI document M100S22. Wayne, Pennsyslvania, 32: 3.

Cowan ST and Steel KJ. 1974. Cowan and steel manual for identification of Medical Bacteria $2^{\text {nd }}$ Edition Cambridge University Press. Cambridge, UK. pp 28-106.

Daodu OB, Elizabeth EA and Oluwayelu DO. 2017. Antibiotic resistance profiling and microbiota of the upper respiratory tract of apparently, South West Nigeria. Afr J Infect Dis., 11 (1): 1-11.

Dar GH, Kamili AN, Chishti MZ, Dar SA, Tantry TA and Ahmad F. 2016. Characterization of Aeromonas sobria isolated from fish Rohu (Labeo rohita) collected from polluted pond. $J$ Bacteriol Parasitol., 7: 273 doi:10.4172/2155-9597.1000273.

Dias C, Mota V, Martinez-Murcia A and Saavedra MJ. 2012. Antimicrobial Resistance Patterns of Aeromonas spp. Isolated from Ornamental Fish. J Aquacult Res Dev, 3:131
El-Bouhy ZM, El-Nobi G, Reda RM and Ali SA. 2015. Prevalence of Septicemia and Red Mouth Disease Caused by Aeromonas sobriaatSahl El-Housinia Fish Farm Zag. Vet. J., 43( 3): 53-63.

FAO. 2017. Regional review on status and trends in aquaculture development in subSahran Africa -2015 . FAO Fisheries and Aquaculture circular No.1135/4,Rome, Italy.

Goharrizi LY, Zorriehzahra MEJ and Adel M. 2015. The study on effect of temperature stress on occurrence of clinical signs caused by Aeromonas hydrophila in Capoeta damascina in in vitro condition. Adv. Anim. Vet. Sci., 3(7): 406-412.

Hussain IA, Jeyasekaran G, Shakila RJ, Raj KT and Jeevithan E. 2014. Detection of hemolytic strains of Aeromonas hydrophila and $A$. sobria along with other Aeromonas spp. from fish and fishery products by multiplex PCR. Int $J$ Food Sci Tech., 51(2),401-407.

Igbinosa IH, Igumbor EU, Aghdasi F, Tom $\mathrm{M}$ and Okoh AI. 2012. Emerging Aeromonas species Infections and Their Significance in Public Health. Sci. World J., Janda JM and Abbott SL. 2010.The genus Aeromonas: taxonomy, pathogenicity, and infection. Clin Microbiol Rev., 23: 35-73.

KDGC (Kaduna state geographical center), 2017. www.kadunastate.gov.ng Accessed 11 March, 2019.

Kumar R, Pande V, Singh L, Sharma L and Saxena N. 2016. Pathological findings of experimental Aeromonas hydrophila infection in golden mahseer (Tor putitora) Fish Aquacult. J., 7:160-165

Kwaga KJ, Kwanashie CN, Dusai DHM and Oni OO. 1988. Occurrence and antimicrobial susceptibility of Pleisiomonas shigelliodes, Aeromonas hydrophila and Edwardsiella tarda in healthy fish in Zaria. Nigerian Journal of Food and Agriculture., 2:176-181.

Long A, Fehringer TR, LaFrentz BR, Call DR, and Cain KD. 2014. Development of a waterborne challenge model for Flavobacterium psychrophilum. FEMS Microbiol Lett., 359:15460.

Lee SW and Wendy W. 2011. Antibiogram and Heavy Metal Resistance Pattern of Salmonella spp. Isolated from Wild Asian Sea Bass (Lates calcarifer) from Tok Bali, Kelantan, Malaysia , Jordan J. Biol. Sci 4(3):125 - 128.

Mailafia, S., 2003. Studies on Aeromonas species isolated from fishes in Zaria, Nigeria. M.Sc.Thesis, Ahmadu Bello University, Zaria, pp.23-34.

Mohamed M. 2018. Aeromonas hydrophila in fish and humans; prevalence, virulotyping and antimicrobial resistance. Slov Vet Res., 55: 636- 9

Mzula A, Philemon NW, Robinson H, Mdegela G and Shirima M. 2019. Phenotypic and molecular detection of Aeromonads infection in farmed Nile tilapia in Southern highland and Northern Tanzania. Heliyon.., 5(8):02220.

Nahar S, Rahman M, Ahmed G, and Faruk M. 2016. Isolation, identification, and characterization of Aeromonas hydrophila from juvenile farmed pangasius (Pangasianodon hypophthalmus). Int. J. Fish. Aquat. Stud., 4: 52-60.

Noga EJ. 2000. Fish disease diagnosis and treatment. Iowa State University, Iowa, USA.

Obiero O, Herwig W, Bryan ON, Jonathan MM, Julius OM and Boaz KA. 2019. Predicting uptake of aquaculture technologies among smallholder fish farmers in Kenya Aquac Int., 27:16891707.

Odeyemi OA and Ahmad A. 2017. Antibiotic resistance profiling and phenotyping of Aeromonas species isolated from aquatic sources. Saudi J. Biol. Sci., 24(1): 65-70. 
Okpokwasili, GC. and Ogbulie L. 1999. Haematological and histological responses of Clarias gariepinus and Heterobranchus bidosalis to some bacterial disease in River state Nigeria. J. Nat. Sci. Res., 27: 1-16.

Omeje VO and Chukwu C. 2012. A relative prevalence of Oreochromis niloticus, Clarias gariepinus and Heterotis niloticus to Aeromonas hydrophila in an integrated fish farm.Niger. Vet. J., 33 (2):492 - 498

Omeje VO and Chukwu CC.2014. Prevalence of Aeromonas hydrophila Isolates in cultured and Feral Clarias gariepinus of the Kainji Lake Area, Nigeria. Niger. Vet. J., 35 (1)9-8 955.

Opiyo MA, Marijani, E, Muendo, P, Odede R, Leschen W and Charo-Karisa H. 2018. A review of aquaculture production and health management practices of farmed fish in Kenya .Int. J. Vet. Sci. Med.., 6: 141-148.

Pękala-Safińska A. 2018. Contemporary Threats of Bacterial Infections in Freshwater Fish. .J Vet Res., 62(3), 261-267.

Plumb JA, Larry A and Hanson LA. 2011. Health maintenance and principal microbial diseases of cultured fishes: In $3^{\text {rd }}$ edition Blackwell Publishing Ltd, Iowa. Pp 492 John Wiley \& Sons.

Raman R, Prakash C, Marappan, M, and Pawar NA.2013. Environmental stress mediated diseases of fish: an overview. In: Advances in Fish Research, Vol.-V, Publisher: Narendra Publishing House, Delhi, India, pp.141-158.
Salunke G, Namshikar V, Gaonkar Rand Gaonkar T. 2015. A case of Aeromonas hydrophila meningitis in septic shock. Trop J Med Res., 18:54-7.

Shiranee P, Natarajan P and Dherendran R..1993. The role of gut and sediment bacterial flora in the nutrition of cultured pearl spot (Etroplussaratensis, Bloch). Isr J Aquac., 45(2): 45-58.

Stratev D and Odeyemi OA . 2015. Antimicrobial Resistance of Aeromonas hydrophila Isolated from Different Food Sources: A Mini-Review.J Infect Public Heal., 9:535-544.

Stratev D, Stoev S, Vashin I, Daskalov H. 2015.Some varieties of pathological changes in eximentalper infection of carps (Cyprinus carpio) with Aeromonas hydrophila. J. Aquacult. Eng. Fish. Res., 1:191-2.

Ugwem UG , Ojo A A and Funkeye E. 2011Haematological Responses of Wild Nile Tilapia Oreochromis niloticus after Acclimation to Captivity. Jordan J. Biol. Sci 4: 225 - 230.

Wegener HC and Frimodt-Moller N. 2000. Reducing the use of antimicrobial agents in animals and man. J. Med. Microbiol., 49:111-115. 